Ijtihad: Jurnal Wacana Hukum Islam dan Kemanusiaan

Vol. 19, No. 1 (2019), pp. 89-102, doi : 10.18326/ijtihad.v19i1.89-102

\title{
Breach of contract: an Indonesian experience in credit akad of sharia banking
}

\author{
Ayup Suran Ningsih \\ Fakultas Hukum, Universitas Negeri Semarang \\ E-mail:ayunpp@mail.unnes.ac.id
}

\section{Hari Sutra Disemadi}

Fakultas Hukum, Universitas Diponegoro

E-mail: haridisemadi@gmail.com

DOI : 10.18326/ijtihad.v19i1.89-102

This research aimed at determining and analyzing the implementation of profit-sharing concept in Islamic banking credit agreements based on regulations in force in Indonesia and also finding out the defaults undertaken by customers in Islamic banking credit agreements. The method used in this research was normative juridical, meant as a method that puts forward secondary data in the form of primary, secondary and tertiary legal materials. The secondary data in question were such as Law Number 21 of 2008 concerning Sharia Banking, related books, and legal research journals. This research was based on the high community needs for capital to achieve the objectives of a business into a separate phenomenon. This research found that the concept of muamalah on the teachings of Islam that Muslims want to adhere to is one of the reasons for the birth of the concept of Islamic banking in Indonesia. Besides, the concept of profit sharing is one of the concepts known in Islamic banking. Another finding of this research was that the risk of breach of contract by the customer is a necessity.

Penelitian ini bertujuan untuk mengetahui dan menganalisis pelaksanaan konsep bagi hasil pada akad kredit perbankan syariah berdasarkan peraturan yang berlaku di Indonesia dan juga untuk mengetahui dan menganalisis wanprestasi yang dilakukan oleh nasabah pada akad kredit perbankan syariah. Metode yang digunakan pada penelitian ini adalah yuridis normatif, yaitu metode yang mengedepankan data sekunder berupa bahan hukum primer, sekunder dan tersier. Data sekunder yang dimaksud seperti Undang-Undang Nomor 21 tahun 2008 tentang Perbankan Syariah, bukubuku terkait dan jurnal penelitian hukum. Penelitian ini didasari atas tingginya kebutuhan masyarakat 
akan modal (capital) demi tercapainya tujuan atas suatu usaha menjadi fenomena tersendiri. Konsep muamalah pada ajaran agama Islam yang ingin ditaati oleh masyarakat muslim menjadi salah satu alasan lahirnya konsep perbankan syariah di Indonesia. Konsep bagi hasil adalah salah satu konsep yang dikenal dalam perbankan syariah. Resiko akan terjadinya breach of contract oleh nasabah adalah suatu keniscayaan.

\section{Keywords: Breach of Contract, Credit Akad, Sharia Banking}

\section{Introduction}

Indonesia is a country with the largest Muslim population in the world, thus Indonesia has the opportunity to become a country with the highest development of sharia economic asset values in the world. Sharia-based economies grow and develop together with the birth and development of Islam in this world (Pratama, Disemadi \& Prananingtyas, 2019: 222). In carrying out its business, Sharia banks implement sharia principles, the principles of Islamic law in banking activities based on a fatwa issued by an institution that has the authority to stipulate a fatwa in sharia (Law Number 21 of 2008 concerning Sharia Banking). Regulations regarding Sharia banks are contained in several laws and regulations, including Law Number 7 of 1992 concerning Banking as amended by Law Number 10 of 1998 concerning Amendment to Law Number 7 of 1992 concerning Banking and Law Number 21 of 2008 concerning Sharia Banking. Sharia banks conduct business activities based on sharia principles. The principle of sharia banking in carrying out its business is one part of Islamic teachings relating to the economy which among others uses the principle of profit sharing and the prohibition of the element of riba.

Based on Law No. 21 of 2008 concerning Sharia Banking, the concept used in sharia bank credit agreements is profit sharing or other name is nisbah. With the principle of profit sharing, Sharia banks can create a sound and fair investment climate because all parties can share both the benefits and risks that arise so that they will create a balanced position between the bank and its customers. In the long run, this will encourage equitable distribution of the national economy because profits are not only enjoyed by capital owners, but also by capital managers. 
This research is about how the implementation of the profit sharing concept in sharia banking credit contract based on Law Number 21 of 2008 concerning Sharia Banking and implementation of breach of contract customers of Sharia Banking credit contract.

Based on Law Number 21 of 2008 concerning Sharia Banking Law, Sharia banks are those that operate their business based on sharia principles and according to their type consist of sharia commercial banks and sharia public finance banks (Article 1 No. 7 of the Law concerning Sharia Banking). Sharia Bank is a financial institution that functions as an intermediary for parties with excessive funds with those who lack funds for business activities and other activities in accordance with Islamic law. If seen in terms of terminology, Islamic banks consist of two words, (a) bank, and (b) sharia. The word bank means a business entity that collects funds from the community in the form of deposits and distributes them to the community in the form of loans and/or other forms in order to improve people's lives. The word sharia in the version of Islamic banks in Indonesia is an agreement based on what is done by other parties for depositing funds or financing business results with other activities in accordance with Islamic law (Ali, 2010: 1).

Sharia banking in Indonesia was presented with the establishment of Bank Muamalat Indonesia which began operations on 1 May 1992. The operation of the bank was based on law number 7 of 1992 concerning Banking (Agung, 2012: 1). Sharia principles are rules of agreement based on Islamic law between banks and other parties to save financing funds for business activities or other activities that are declared sharia-compliant, including financing based on the principle of profit sharing (mudharabab), financing with the principle of equity participation (musyarakah), the principle of buying and selling goods with profit (murabahah), financing of capital goods based on the principle of pure rent without choice (ijarah), or the choice of transfer of ownership or goods leased from the bank by another party (ijarah wa iqtima) (Ali, 2010: 3).

In Article 25 of Law Number 21 of 2008 concerning Sharia Banking, there are several types of contracts (akad), including the sharing of profit sharing contracts in the form of mudharabah and musyarakah, contracts for lending and borrowing transactions in the form of qardh accounts. Credit contracts or lending and borrowing in sharia banks are known as mudharabah which can be interpreted by a person's process of carrying out business (Ali, 
Ijtihad: Jurnal Wacana Hukum Islam dan Kemanusiaan, Volume 19, No. 1, Juni 2019: 89-102

2010: 41). Technically, mudharabah is a contract of cooperation between parties where the first party (Shahib al-mal) provides all capital, while the other party becomes the manager (Ali, 2010: 41). Business profits in mudharabah are divided according to the agreement stated in the contract. If the loss is borne by the capital owner as long as it is not the manager's negligence. However, if the loss is caused by negligence or fraudulent management, then the manager must be responsible for the losses incurred. In the mudharabah contract, for financing products, it is also called profit sharing (Adnan, 1996: 47).

\section{The concept of breach of contract according to private law}

Breach of contract is a situation where the debtor does not fulfill the agreed upon performance. There are two possibilities for breach of contract, which is because of negligence, mistake and/or because of an over macht (Busro, 2012: 20). Breach of contract that causes because there are two that are not in it are those that are intentional and negligent. Intentionality has a higher level than due to negligence (Busro, 2012: 20).

In the debtor's self, there is an obligation to fulfill the achievement and if the achievement is not carried out, the debtor is said to have taken an action called breach of contract or breach of contract (Ningsih, Suprati \& Fibrianti, 2019: 226). So the debtor has the breach of contract or breach of contract if it is supposed to fulfill the obligations that have been agreed upon but it turns out that denying that achievement is not fulfilled. The breach of contract or breach of contract are 3 (three): 1). The debtor does not fulfill the achievement at all; 2). Debtors are late in fulfilling their achievements; and 3). Debtors do not fulfill the achievement as they should (Busro, 2012: 19).

In the Civil Code, breach of contract was provided in article 1243: Penggantian biaya, rugi dan bunga karena tak dipenubinya suatu perikatan, barulah mulai diwajibkean, apabila si berutang, setelah dinyatakan lalai memenubi perikatannya, tetap melalaikannya, atau jika sesuatu yang harus diberikan atau dibuatnya, hanya dapat diberikan atau dibuat dalam tenggang waktu yang telah dilampaukannya. (Reimbursement of costs, losses, and interest due to not fulfilling an agreement, then begin to be obliged, if the debtor, after being declared negligent in fulfilling the agreement, still neglects it, or if something must be given or made, can only be given or made within the time limit). 
Breach of contract: an Indonesian experience in akad credit of sharia banking (Ayup Suran Ningsih)

\section{Research methods}

The approach method used by the researcher is a normative juridical approach. The normative juridical approach is to identify and conceptualize the law about breach of contract (Soekanto, 1986: 51). This approach emphasizes to find out and analyze the implementation of the profit sharing concept in sharia banking credit contract based on Law Number 21 of 2008 concerning Sharia Banking and also to know and analyze the implementation of breach of contract customer on sharia banking credit contract.

\section{Results and discussion}

\section{The concept of profit sharing in sharia banking}

The legal basis regarding Sharia banks refers to Law Number 7 of 1992 concerning Banking as amended by Law Number 10 of 1998 concerning Amendments to Law Number 7 of 1992 concerning Banking (Law 10/1998) and Law Number 21 of 2008 concerning Sharia Banking (Law 21/2008).

According to Law 10/1998, Sharia Principles are agreements based on Islamic law between banks and other parties for depositing funds and/or financing business activities, or other activities declared in accordance with sharia, including financing based on the principle of profit sharing (mudharabah), financing based on the principle of equity participation (musharakah), the principle of buying and selling goods by obtaining profits (murabaha), or financing capital goods based on the principle of pure rent without choice (ijarah), or by the ownership transfer of goods leased from the bank by another party (ijarah wa iqtina).

Sharia Principles according to Law 21/2008 are the principles of Islamic law in banking activities based on a fatwa issued by an institution that has authority in establishing fatwas in the field of sharia. Business activities based on Sharia Principles include business activities that do not contain elements: 1). riba, which is the addition of illegal income (bati), among others, in the exchange of similar goods that do not match the quality, quantity, and delivery time $(f a d h)$, or in lending transactions that require Facility Recipient Customers to return funds in excess of the principal loan because of the passage of time (nasiab); 2). maisir, i.e. 
Ijtihad: Jurnal Wacana Hukum Islam dan Kemanusiaan, Volume 19, No. 1, Juni 2019: 89-102

transactions that depend on an uncertain and chancy condition; 3). gharar, i.e. transactions where the object is unclear, not owned, unknown, or cannot be delivered when the transaction is carried out unless otherwise stipulated in sharia; 4). haram, i.e. transactions whose objects are prohibited in sharia; or 5). ralim, i.e. transactions that cause injustice to others.

In the General Explanation of Law 21/2008, it is also said that Sharia Principles are based on the values of justice, expediency, balance and universality (rabmatan lil 'alamin). These values are applied in banking arrangements based on Sharia Principles called Sharia Banking. Principles of Sharia Banking are part of Islamic teachings relating to the economy. One of the principles in Islamic economics is the prohibition of riba in various forms, and using the system, among others the principle of profit sharing (mudharabab) (Hikmah, 2019: 23).

Regarding the emphasis on sharia principles in Sharia banking can also be seen in Bank Indonesia Regulation Number 9/19/PBI/2007 concerning Sharia Principles Implementation in Activities of Fundraising and Funds Distribution and Sharia Bank Services (PBI 9/2007) as amended with Bank Indonesia Regulation Number 10/16/ PBI/2008 Year 2008 (PBI 10/2008).

Profit sharing in PBI 10/2008 is one form of financing. What is meant by financing is the provision of funds or bills equalized in the form (Article 1 number 8 PBI 10/2008): 1). Profit sharing transactions in the form of mudharabah and musyarakab; 2). Lease transactions in the form of ijarah or lease purchase in the form of ijarah muntabiya bittamlik; 3). Buying and selling transactions in the form of murabahah, salam, and istishna receivables'; 4). Lending and borrowing transactions in the form of qardh receivables; and 5). services leasing transactions in the form of ijarah for multi-purpose transactions, based on an agreement or agreement between a Sharia Bank and / or Sharia Business Unit and other parties requiring parties to be financed and / or given funds to return the funds after a certain period of time with ujrah benefits, without compensation, or profit sharing as referred to in Law 21/2008.

There are fundamental objections raised by the advocates of the development of Sharia banks towards the conventional banking system which have quite influenced the development of the Sharia banking world itself. The fundamental objections include the following: 1). Related to the structural problem of the contract (akad) that uses a system 
of interest which is believed or at least considered to resemble riba which is absolutely prohibited by sharia; and 2). The absence of a guarantee that investment activities carried out by conventional banks consider aspects of object halalness and how to manage them, in other words, religious values and morals are not an important factor in bank business activities. Therefore, the guarantee of legality in sharia (sharia compliance) of all customer fund management activities by banks is very important in the business activities of sharia banks (Perwataadmadja, 1999).

Above considerations, it is the basis for various parties to make integrated efforts towards the development of banks based on Sharia principles. Broadly speaking, the difference in the operating system in conventional banks and sharia banks is that the financial operating system uses the bank interest system, in contrast to the sharia bank which has the characteristics of the profit sharing system in all transactions (Archer \& Karim, 2009: 300).

\section{The consequence of breach of contract in sharia banking}

Indonesian banking has an important function in economic development. In addition to its main function as an intermediary, which brings together the owners of funds (surplus of funds) with the users of funds (lack of funds), banks have a strategic role in driving the Indonesian economy, as agents of development, agents of services and agents of trust (Disemadi, 2019: 197). Profit sharing is a general characteristic and the basic foundation for the operation of the sharia bank as a whole. In principle sharia is based on the rules of al mudharabah. Based on this principle, Sharia bank will function as good partners with savers as well as entrepreneurs who borrow funds. With savers, banks will act as mudarib (managers) while savers as shabibul maal (funders). Between the two, there is a mudharabah agreement that states the distribution of benefits of each party (Algaoud \& Lewis, 2001: 75).

On the other hand, with entrepreneurs / debtors of funds, Sharia banks will act as shabibul maal (funders - both from savings / deposits / current accounts and bank funds in the form of shareholder capital). Meanwhile, entrepreneurs / debtor will function as the mudharib (manager) because it does business by turning and managing bank funds. Same with conventional banks, Sharia banks also have a role as intermediary institutions 
between units of community groups or economic units that experience excess funds (surplus units) with other units that experience a lack of funds (deficit units). Through the excess bank, these funds can be channeled to parties who need and provide benefits to both parties.

Interest-based banks carry out this role through their activities as debtors and creditors. Fund owners are interested in depositing funds in the bank based on the promised interest rate. Similarly, banks provide loans to parties who need funds based on their ability to pay certain interest rates. The relationship between the bank and the customer is the relationship between the creditor and the debtor.

Murabahab contract (akad) is a sale and purchase transaction of an item in the amount of the cost of goods plus a margin agreed upon by the parties, where the seller informs the buyer of the price in advance (Muhammad, 2014: 46). Sharia banks take murabahah to provide short-term financing to their clients to buy goods even though the client may not have the cash to pay. Murabahah, as used in Sharia banking, is determined primarily based on two elements, the price of purchase related, and the opportunity based on mark-up (profit). Profit margin is the difference in selling price minus the original price which is the bank's contract. Payment of the price of goods is done in a formidable manner or in other words paid in full at a certain agreed time (Dewi, 2007: 88). In terms of murabahah, several terms and conditions are applied which must be known by customers who will conduct murabahah transactions on credit.

The price agreed in murabahah is the selling price while the purchase price must be notified. If the bank gets a discount from the supplier, then the discount is the customer's right. If the deduction occurs after the contract, the distribution of the deduction is made based on the agreement contained in the contract (Waluyo, 2016: 526).

Unlike conventional banks, the relationship between Sharia banks and their customers is not the relationship between the debtor and the creditor, but rather the partnership relationship between the funder (Shahib al Maal) and the fund manager (mudharib). Therefore the profit rate of Sharia Banks not only influences the level of profit sharing for shareholders but also affects the profit-sharing that can be given to customers saving funds. Thus the ability of management to carry out its functions as a store of assets, entrepreneurs 
and good investment managers (professional investment managers) will greatly determine the quality of its business as an intermediary institution and its ability to generate profits.

The implementation of operations in Sharia banks applies the principle of Sharia while conventional banks apply a system of interest. This difference in operating system has resulted in fundamental differences in the structure of corporate governance and supervision systems in sharia activities.

The function of Sharia banking supervision as mandated in the Law aims to support efforts to realize healthy Sharia banking, operate prudently, fulfill various applicable banking provisions, protect the interests of the public using banking services and consistently implement sharia principles. The Sharia banking supervision approach uses an integrated pattern that integrates indirect supervision (off-site supervision) and direct supervision or field inspection (on-site supervision) and adopts a risk-based bank supervision approach. The supervisory activities carried out off-site and on-site are directed at maintaining the soundness of the bank and supporting the achievement of the bank's business plan while paying attention to the principle of prudence and compliance with sharia principles. Offsite supervision activities are carried out by analyzing financial conditions through the SIMWAS (Supervision Management Information System) and reports submitted by banks, as well as assessing bank compliance with applicable regulations(Hidayati, 2008: 68).

Sharia banking supervision basically has two systems, as follows: 1). Supervision of the financial aspects, compliance with the general multiplication and bank prudential principles; and 2). Supervision of sharia principles in bank operations. This supervision is carried out by institutions authorized to supervise the implementation of Sharia banks in carrying out their business. Sharia banks have a DPS (Sharia Supervisory Board) in their banks. DPS is in charge of overseeing all bank activities to always comply with sharia principles. In other words, DPS is responsible for the products and services offered to the community to conform to sharia principles; investments or projects handled by banks must also be in accordance with sharia principles, and of course, the bank itself must be managed in accordance with sharia principles (Hidayati, 2008: 67-68).

The authority in Indonesia on religious matters is under the Indonesian Ulama Council (MUI). The development of Sharia financial institutions in Indonesia also led to the 
development of the number of DPS (Faozan, 2013: 9). To anticipate that there will be no confusion in the community due to the many and varied DPS, so that MUI as an umbrella of Islamic institutions and organizations in Indonesia considers the need for the establishment of a national sharia council and oversees all financial institutions (Antonio, 2001: 79). Banks can ask customers to provide collateral for murabahah receivables, among others, in the form of goods that have been purchased from the bank. The bank can request urbun to the customer as a purchase down payment at the time of contract if both parties have agreed. Urbun becomes the repayment part of murabahah receivables if the murabahah is implemented. But if the murabahah is canceled, the urbun is returned to the customer after deducting the loss in accordance with the agreement. If the down payment is smaller than the bank's loss, then it can request additional from the customer (Muhamad, 2004: 232).

The implementation of credit certainly does not always run without obstacles. Sometimes there are customers who experience bad credit. In Article 1243 of the Civil Code, this is called a breach of contract where a debtor does not give his achievement. In this case, the achievement is in the form of installments in the credit. If there is an obstacle in the installment payment process, the bank has the right to impose a fine on the customer. A customer who has economic financial capacity is prohibited from delaying payment.

Bank can take action with legal procedures in order to recover the debt and submit financial loss claims that occur due to delays, customers who are negligent in payments, the Bank tends to take action in a family manner (negotiation), but if indeed the customer cannot pay in a timely manner. has been determined and still has the ability to pay it will be visited by the bank.

The bank will negotiate and to find out the reason for not paying the installments. As for if the customer does not want to pay, the bank can carry out asset seizures. Whereas for customers who are in bankruptcy and fail to settle their debts because they are truly economically inadequate until they are stuck and not due to negligence.

The customer must bond well by reporting on the economic situation, the bank will negotiate with the customer regarding the possibility of providing concessions or additional tempo so that he is able to pay his obligations or also called restructuring. Banks as creditors have an obligation to foster and provide management assistance and provide 
relief to debtors in resolving their debts. Credit settlement through the credit rescue stage is called settlement through credit restructuring.

The completion step through credit restructuring requires the most important conditions, the willingness and good faith of the debtor and is willing to follow the conditions set by the bank because of the credit settlement through restructuring more negotiations and solutions offered by the bank to determine the terms and conditions of the restructuring (Rismayani, Puspawati \& Sutama, 2013: 4).

Debt restructuring is a debt payment with terms that are softer or lighter than the terms of debt repayment before the debt restructuring process is carried out because there are special concessions given by creditors to the debtor. This kind of decision is not given to the debtor if the debtor is not in a state of financial difficulties. Such decisions can come from agreements between creditors and debtors, or from court decisions, as well as from legal regulations. From this understanding, it can be concluded that those who have an interest in debt restructuring are the debtors who have problems. Troubled debt restructuring can occur before, on, or after the debt due date stated in the agreement, and there will be a time span between the time of the agreement, the court decision, and so on. With the effective date of the new requirements or the occurrence of other events which constitute the implementation of restructuring, what is meant by the effective date of implementation is the time of restructuring. If the allowance has expired, the customer is still unable to pay, the bank may take the initiative to confiscate the guarantee while maintaining and not reducing the customer's rights at all.

The customer criteria are subject to fines as follows: a). Delay in paying; b). There is money but it is lazy to pay/afford. Example: a decade, the customer turns out to have money but is used for other business or other purposes first: and c). Bad character/intention. Example: Should receive the time to pay and announce not paying, the party bank calls, after there is no response. The final step that can be taken in repayment of debt due to the breach of contract is by auction guarantee. An auction is the sale of goods that are open with a written or oral price quote that is increasing or decreasing to reach the highest price preceded by the announcement of the auction. The collateral auction is one form of the auction which is regulated in the rules of auction implementation, classified as a mandatory 
Ijtihad: Jurnal Wacana Hukum Islam dan Kemanusiaan, Volume 19, No. 1, Juni 2019: 89-102

execution auction, and carried out at the State Wealth Service Office (KPKNL).

In sharia banking, mortgage rights are a form of the application of prudence that is carried out based on sharia principles as well as the manifestation of mutual assistance, helping others especially those who are in dire need. The concept of land in the implementation of mortgage rights is realized by sub-sale, even though the process is contrary to Article 55 of Law No. 21 of 2008 concerning Sharia Banking, but in its implementation Sharia banks prefer the sales process under the hand, considering the process of selling below hands can get higher prices and do not conflict with sharia principles. The process of selling under the hands is carried out based on the agreement of both parties with supervision from the bank.

\section{Conclusion}

Breach of contract made by the debtor causes losses to the creditor, and the losses incurred by the debtor has a mechanism for compensation. There are several alternatives stipulated in the Banking Law and the Sharia Banking Law in the event of the breach of contract by debtors, the recalculation of debt (restructuring) is one of them. Restructuring is not only done on conventional banks but also can be done on Sharia banks. According to the results of the observation, the option to auction the collateral object can also be done, but the bailout is the last option if the debtor has indeed failed (bankrupt).

The implementation of credit agreements (akad) in Sharia banks continues to use the principles contained in article 1243 of the Civil Code in the event of the breach of contract. Business profits by mudharabbah or also called profit sharing are divided according to the agreement stated in the contract. Services paid by customers have been agreed at the beginning when making a credit agreement. If the loss is borne by the capital owner as long as it is not the manager's negligence. However, if the loss is caused by negligence or fraudulent management, then the manager must be responsible for the losses incurred. In the mudharabbah contract, for financing products, it is also called profit sharing. Sharia banks are not operating an interest in carrying out their operations but using profit sharing mechanisms and are always supervised by the Sharia Supervisory Board (DPS) in each of its operational activities, so it is hoped that Sharia banks will always be within the corridors 
Breach of contract: an Indonesian experience in akad credit of sharia banking (Ayup Suran Ningsih)

of Islamic law. Besides that, it also must not contain elements that are prohibited by Shari'a, maisir (gambling), gharar (obscurity), riba (additional) and bathil (injustice). This can be avoided by the existence of murabahah or sale and purchase contracts, buying and selling goods with a selling price consisting of the purchase price plus agreed profits. The installment payment on the murabahah continues until the end of the contract because it is not affected by fluctuations in interest rates on the market. That is why there are clarity and injustice in the murababah agreement.

\section{Bibliography}

Adnan, Muhammad Akhyar. An Investigation Of Accounting Concepts And Practices In Islamic Banks The Case Of Bank Islam Malaysia Berhad AndBank Muamalat Indonesia. Wollongong: University Of Wollongong, Disertasi Doctor. 1996.

Agung, Bagya. Aspek Hukum Pembiayaan Murabahah Pada Perbankan Syariah. Yogyakarta: UII Press, 2012.

Algaoud, Latifa M., dan Mervyn K. Lewis. Islamic Banking. Massachusett: Edward Elgar, 2001.

Ali, Zainuddin. Hukum Perbankan Syariah. Jakarta: Sinar Grafika, 2010.

Antonio, Muhammad Syafi'i. Bank Syariah Dari Teori ke Praktek. Jakarta: Gema Insani, 2001.

Archer, Simon, and Rifaat Ahmed Abdel Karim. "Profit-Sharing Investment Accounts In Islamic Banks: Regulatory Problems And Possible Solutions”, Journal of Banking Regulation, 10(4), 300-306, 2009.

Busro, Achmad. Hukum Perikatan Berdasar Buku II KUHPerdata. Yogyakarta: Pohon Cahaya. 2012.

Dewi, Gemala. Aspek-aspek Hukum dalam Perbankan dan Perasuransian Syariah di Indonesia. Jakarta: Kencana Prenada Media Group, 2007.

Disemadi, Hari Sutra. "Risk Management In The Provision Of People's Business Credit As Implementation Of Prudential Principles", Diponegoro Law Review 4(2), 194-208, 2019.

Faozan, Akhmad. "Implementasi Good Corporate Governance Dan Peran Dewan Pengawas Syariah Di Bank Syariah", La_Riba: Jurnal Ekonomi Islam, 7(1), 1-14, 2013. 
Ijtihad: Jurnal Wacana Hukum Islam dan Kemanusiaan, Volume 19, No. 1, Juni 2019: 89-102

Hidayati, Maslihati Nur. "Dewan Pengawas Syariah dalam Sistem Hukum Perbankan: Studi Tentang Pengawasan Bank Berlandaskan Pada Prinsip-Prinsip Islam”, Lex Jurnalica, 6(1), 62-76, 2008.

Hikmah, Nurul. "Problems in the Status of Object Ownership of Ijarah Muntahiyah Bittamlik Financing Contract in Sharia Banking Law", J. Priv. \& Com. L, 3(1), 20-25, 2019.

Muhamad. Manajemen Dana Bank Syariah. Jakarta: Rajawali Pers, 2014.

Muhamad. Manajemen Keuangan Syar" ah Analisis Figh \& Kenangan. Yogyakarta: UPP STIM YKPN, 2004.

Ningsih, Ayup Suran, Duhita Driyah Suprapti, and Nurul Fibrianti. “The Importance of Applying the Membership Value Toward Savings and Loans Cooperatives in Indonesia”, Sriwijaya Law Review, 3(2), 225-234, 2019.

Perwataadmadja, Karnaen. "Bank Syariah Sebagai Alternatif Pemecahan Masalah Yang dihadapi Bank Konvensional". Jakarta: Diskusi Perbankan Syariah, Fakultas Hukum Universitas Indonesia, 1999.

Pratama, Angkat Poenta., Hari Sutra Disemadi, and Paramita Prananingtyas. "Existence And Position Of Islamic Economic Laws In Indonesia”, Legality: Jurnal Ilmiah Hukum, 27(2), 222-231, 2019.

Rismayani, Made Andri, I Gusti Ayu Puspawati, and Ida Bagus Putu Sutama. "Restrukturisasi Kredit Sebagai Upaya Bank Untuk Membantu Debitur Dalam Menyelesaikan Tunggakan Kredit Di Pt. Bank Tabungan Negara (Persero) Tbk Denpasar", Jurnal Hukum Bisnis Universitas Udayana, 1-5, 2013.

Soekanto, Soerjono. Pengantar Penelitian Hukum. Jakarta: UI Press, 1986.

Waluyo, Agus. "Kepatuhan Bank Syariah Terhadap Fatwa Dewan Syariah Nasional Pasca Transformasi Ke Dalam Hukum Positif", INFERENSI: Jurnal Penelitian Sosial Keagamaan, 10(2), 517-538, 2016. 